\title{
MORPHOLOGICAL CHARACTERISTICS OF THE TONGUE OF THE ROCK CAVY- Kerodon rupestris WIED, 1820 (Rodentia, Caviidae)
}

\author{
CARACTERÍSTICAS MORFOLÓGICAS DA LÍNGUA EM MOCÓS- Kerodon rupestris \\ WIED, 1820 (Rodentia, Caviidae)
}

\section{Amilton Cesar dos SANTOS'; Marian Mazeto de ARO $^{2}$; Bruno Machado BERTASSOLI ${ }^{3}$; Diego Carvalho VIANA ${ }^{1}$; Bruno Gomes VASCONCELOS ${ }^{4}$; Rose Eli Grassi RICI ${ }^{5}$; Moacir Franco de OLIVEIRA ${ }^{6}$; Maria Angélica MIGLINO; Antônio Chaves de ASSIS-NETO ${ }^{5}$}

1. Doutorandos, Faculdade de Medicina Veterinária e Zootecnia- FMVZ. Universidade de São Paulo - USP, São Paulo, SP, Brasil. antonioassis@usp.br, amiltonsantoss@bol.com.br; 2. Graduanda, Faculdade de Medicina Veterinária e Zootecnia- FMVZ. Universidade de São Paulo - USP, São Paulo, SP, Brasil; 3. Doutorando, Universidade Federal de Minas Gerais- UFMG, Belo Horizonte, MG, Brasil; 4. Professor Doutor, Universidade Federal de Mato Grosso - UFMT, Sinop, MT, Brasil; 5. Professores Doutores, Faculdade de Medicina Veterinária e Zootecnia - FMVZ - USP, São Paulo, SP, Brasil; 6. Professor, Doutor, Universidade Federal Rural do Semiárido UFERSA, Mossoró, RN, Brasil;

\begin{abstract}
The Kerodon rupestris are wild rodents bred in captivity in order to their conservation and development of researches. The aim of this study was describe the morphology of the tongue from eight animals by light microscopy and scanning electron microscopy, beyond macroscopic studies. The tongues of K. rupestris had $3.15 \pm 0.28$ $\mathrm{cm}$ of length; $1.0 \pm 0.20 \mathrm{~cm}$ width at the root; $0.38 \pm 0.10 \mathrm{~cm}$ width at the body; and, $1.10 \pm 0.09 \mathrm{~cm}$ width at the apex. Thickness measurements were $0.50 \pm 0.09 \mathrm{~cm}$ at the apex; $0.30 \pm 0.10 \mathrm{~cm}$ at the body; and, $0.70 \pm 0.10 \mathrm{~cm}$ at the root. The free apex had $0.50 \pm 0.10 \mathrm{~cm}$ in length. The dorsal surface of the tongue contained the fungiform and filiform papillae at the apex and body; conical papillae and a pairs of vallate papillae at the root, and foliated papillae dorsolaterally positioned in the root region. The proper lamina of the dorsal surface of the tongue was composed by keratinized stratified squamous epithelium, in which lingual papillae were found; and, a rich network of skeletal striated muscle and non-modeled dense connective tissue, in which vessels, nerves, mucous and serous acini and their respective ducts were found. In summary, dorsal surface of the tongue of $K$. rupestris had filiform and conical papillae with mechanical function, and, fungiform, vallate and foliated papillae with taste buds responsible by gustatory function. Moreover, the tongue of these animals showed some peculiarities as the eminence on the apex in sagittal plane, which needs further studies.
\end{abstract}

KEYWORDS: Digestory apparatus. Lingual papillae. Oral cavity. Wild rodents.

\section{INTRODUCTION}

The rock cavies Kerodon rupestris are wild rodents, which have been restricted to the semiarid region of Caatinga in the Brazilian Northeastern. They belong to the Caviidae family, Caviinae subfamily (ADRIAN; SACHSER, 2011; RODRIGUES et al., 2013) and Kerodon genus (THOMAZ et al., 2006). Their habit consist of stalking in the afternoon or at night to seek leaves, buds, twigs, fruits, bark, roots and tubers from the shrubs of the Caatinga (OLIVEIRA et al., 2011).

The Caviidae are prey of most South American predators and thus they have important ecological role in the food chain. Moreover, the $K$. rupestris are subject to intense hunting due to their size and tasty meat, which is greatly appreciated by the rural population in the Brazilian Northeastern (ZOGNO; MIGLINO; OLIVEIRA, 2004). For this reason, $K$. rupestris and other Brazilian Caviidae are bred in captivity in order to provide alternative source of proteins, preserve the species and to development of researches (OLIVEIRA et al., 2011; SANTOS et al., 2014).

In this sense, few studies focusing on the digestory apparatus of the $K$. rupestris have been published and they described teeth (THOMAZ et al., 2006) and stomach (BORSARI et al., 2010) morphology. Another important organ of digestory apparatus is the tongue, in which, different types of functional lingual papillae (WITT; REUTTER, 1997; BRANCO et al., 2011, 2012; MANÇANARES et al., 2012) lie on the dorsum, and are variously distributed in different vertebrate species (IWASAKI, 2002; JACKOWIAK; GODYNICKI, 2005; NONAKA; ZHENG; KOBAYASHI, 2008). The aim of this study was describe the morphological characteristics of the tongue of $K$. rupestris, providing more data for future researches. 


\section{MATERIAL AND METHODS}

\section{Animals}

Tongues of four males and four females (adults and healthy) from the Breeding Center (CEMAS) of the Federal Rural University of the Semiarid Region (UFERSA), Mossoró RN Brazil (IBAMA 2028236/2008) were used in present study. The study was approved by the Bioethics Committee of the School of Veterinary Medicine and Animal Science, University of São Paulo, São Paulo SP Brazil ( $n^{\circ}$ 2485/2011). The animals came from other previous studies and they had already been euthanized and fixed in formaldehyde $10 \%$ (four animals) and glutaraldehyde 2.5\% 0.1M (four animals).

\section{Macroscopic Analysis}

The tongues were dissected, removed and then, total length, width and thickness at the apex, body and root were obtained with digital calipers (Mitotuyo, Tokyo, Japan). So, a schematic drawing of the morphology of the tongue for a better view of your shape was performed. The measurements of mean and standard deviation were performed. Photodocumentation was performed by camera Olympus SP 810UZ $14 \mathrm{mp}$.

\section{Scanning Electron Microscopy Analysis (SEM)}

The tongues fixed in glutaraldehyde $2.5 \%$ $0.1 \mathrm{M}$ ( $\mathrm{pH}$ 7.4) were sectioned into three parts: root, body and apex. Then, the fragments were washed with $0.1 \mathrm{M}$ phosphate buffer solution and post-fixed in osmium tetroxide (Spurr's Kit-Electron Microscopy Sciences Co., USA). The fragments of
SANTOS, A. C.

tissues were washed with buffer solution and dehydrated in increasing ethanol series (from 50 to $100 \%$ ), followed by critical point drying (Balzers PCD 020). Then, the fragments were properly fixed in metallic (stubs) and coated in gold (Emitech K550). The analysis was performed with electron microscope Leo 435 VP (Semtech, USA).

\section{Light Microscopy Analysis (LM)}

From the tongues fixed in $10 \%$ formaldehyde, samples of apex, body, root and lateral regions of the root were extracted. Then, the fragments were dehydrated in increasing series of ethanol (from 70 to 100\%) and diaphanized in xylene for inclusion in paraffin blocks. Cuts with $5 \mu \mathrm{m}$ in Leica RM 2155 microtome were obtained and stained with hematoxylin and eosin (HE) in order to analyze the microscopic morphology of the tongue. BX61VS Olympus photomicroscope was used for microscopic photodocumentation.

\section{RESULTS}

\section{Macroscopic analysis}

The tongues of $K$. rupestris had $3.15 \pm 0.28$ $\mathrm{cm}$ of length; $1.0 \pm 0.20 \mathrm{~cm}$ width at the root; $0.38 \pm$ $0.10 \mathrm{~cm}$ width at the body; and, $1.10 \pm 0.09 \mathrm{~cm}$ width at the apex. Thickness measurements were $0.50 \pm 0.09 \mathrm{~cm}$ at the apex; $0.30 \pm 0.10 \mathrm{~cm}$ at the body; and, $0.70 \pm 0.10 \mathrm{~cm}$ at the root. The free apex had $0.5 \pm 0.10 \mathrm{~cm}$ of length (Figure $1 \mathrm{~A}$ and $\mathrm{B}$ ). Morphologically, an intermolar eminence at the root and a lower eminence in the sagittal plane at the apex were noted (Figure 1A and B; 2A).

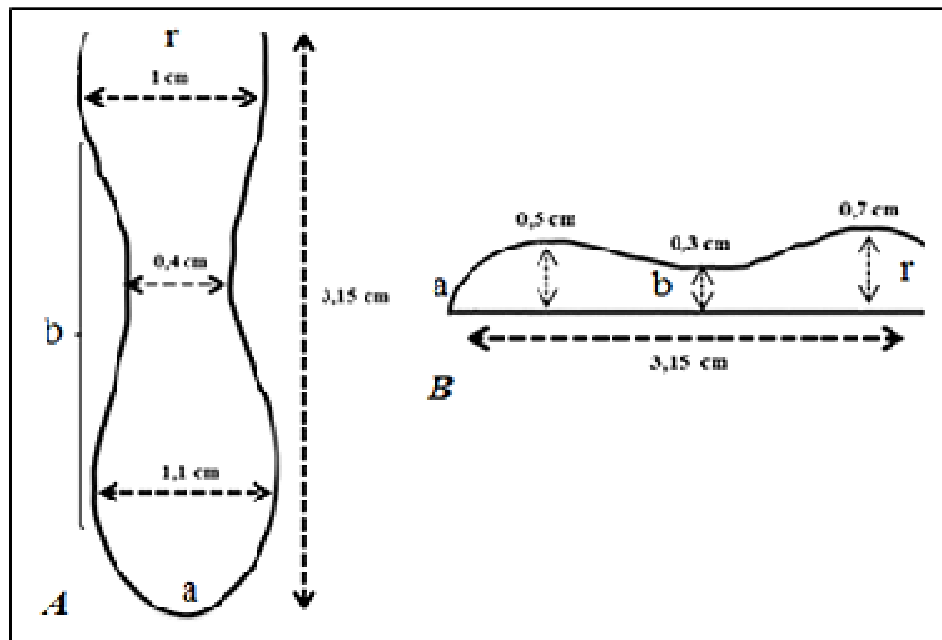

Figure 1. Illustration of the anatomical shape and measurements of the tongue of $K$. rupestris. A: shape and measurements of length and width at the apex (a), body (b), and root (r). B: shape and measurements of length and thickness at the apex (a), body (b), and root (r). 


\section{Scanning Electron Microscopy Analysis (SEM)}

By SEM, we observed that the dorsum of the tongue had several filiform papillae scattered throughout the body and apex (Figure 2D); conical papillae was scattered in the region of the intermolar eminence at root (Figure 2B); fungiform papillae was scattered among the filiform papillae at the body and apex (Figure 2D). A pair of vallate papillae with rectilinear grooves at the root was present (Figure 2B). Foliate papillae at the root was dorsum-laterally positioned (Figure 2C).
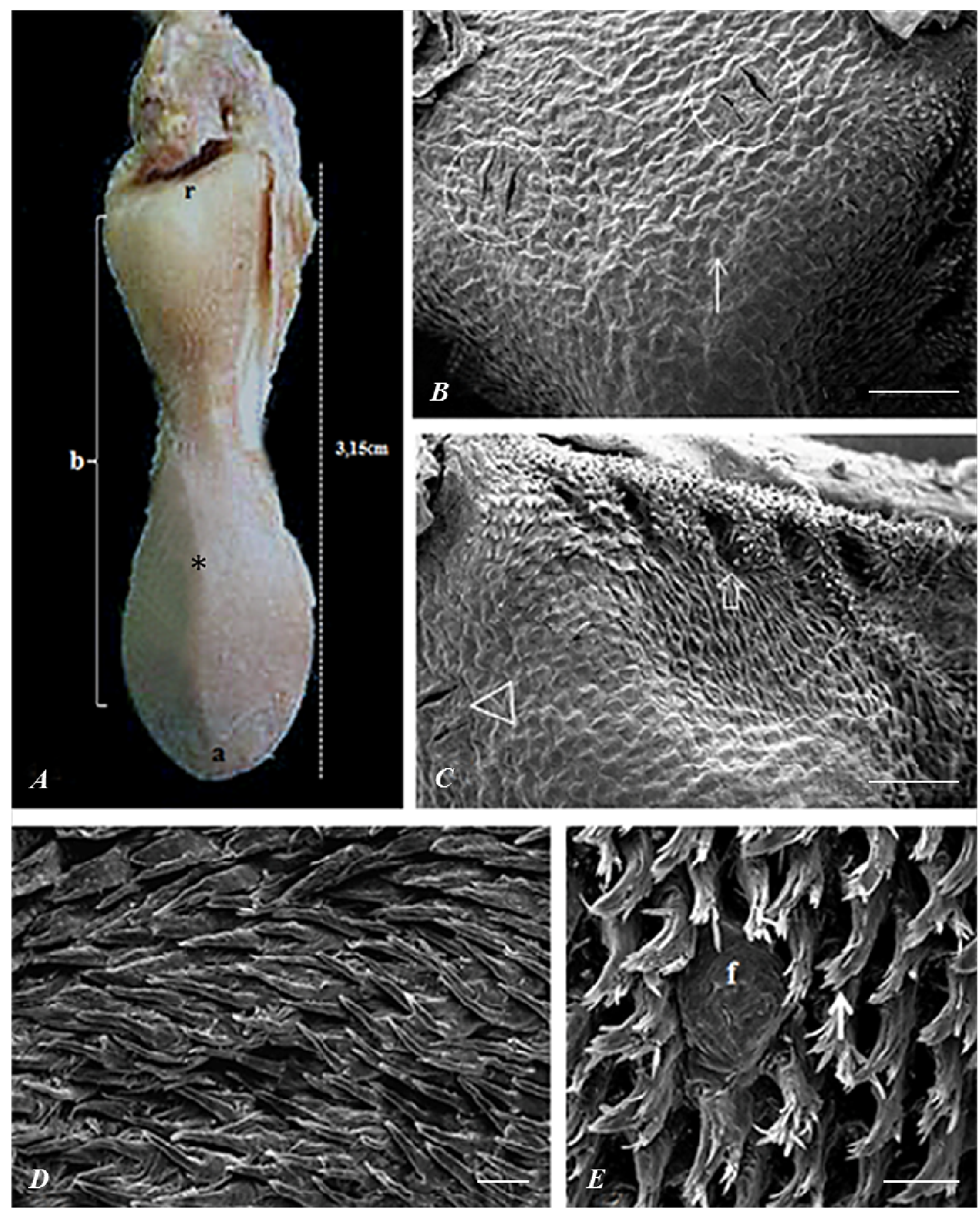

Figure 2. Photography and electron micrograph of the tongue of $K$. rupestris. A: Photograph showing root (r), body (b), and apex (a) and median eminence $(*)$ at the apex. B: electron micrograph showing vallate (circle) and conical papillae (arrow) at the root. Bar: $1 \mathrm{~mm}$. C: electron micrograph from lateral view of root showing foliated papillae (arrow) and vallate papillae (arrowhead). Bar: $1 \mathrm{~mm}$. D: electron micrograph showing foliated papillae at the body. Bar: $100 \mu \mathrm{m}$. E: electron micrograph at the body showing fungiform papillae (f) surrounded by filiform papillae. Bar: $100 \mu \mathrm{m}$. 


\section{Light Microscopy Analysis (LM)}

The proper lamina of the dorsal surface of the tongue was composed by the surface covered with keratinized stratified squamous epithelium, in which several papillae were found and non-modeled dense connective tissue, in which vessels, nerves, mucous and serous acini and their respective ducts were found (Figure 3A, B, E and F; Figure 4A and B). Moreover, a rich network of skeletal striated muscle, with longitudinal, transversal and circular fibers over its entire length and keratinized stratified squamous epithelium in the ventral surface of tongue was found (Figure 3C and D).

Unilocular adipose tissue was found between muscular bundles (Figure 3D). The ventral surface of the tongue had keratinized stratified squamous epithelium and absence of lingual papillae (Figure 3C).

The fungiform (Figure 3B), foliated (Figure 4B and C) and vallate papillae (Fig. 3E) had taste buds (Figure 3E). In the region of the vallate and foliated papillae, serous and mucous acini were found (Figure 3E and F; 4B).
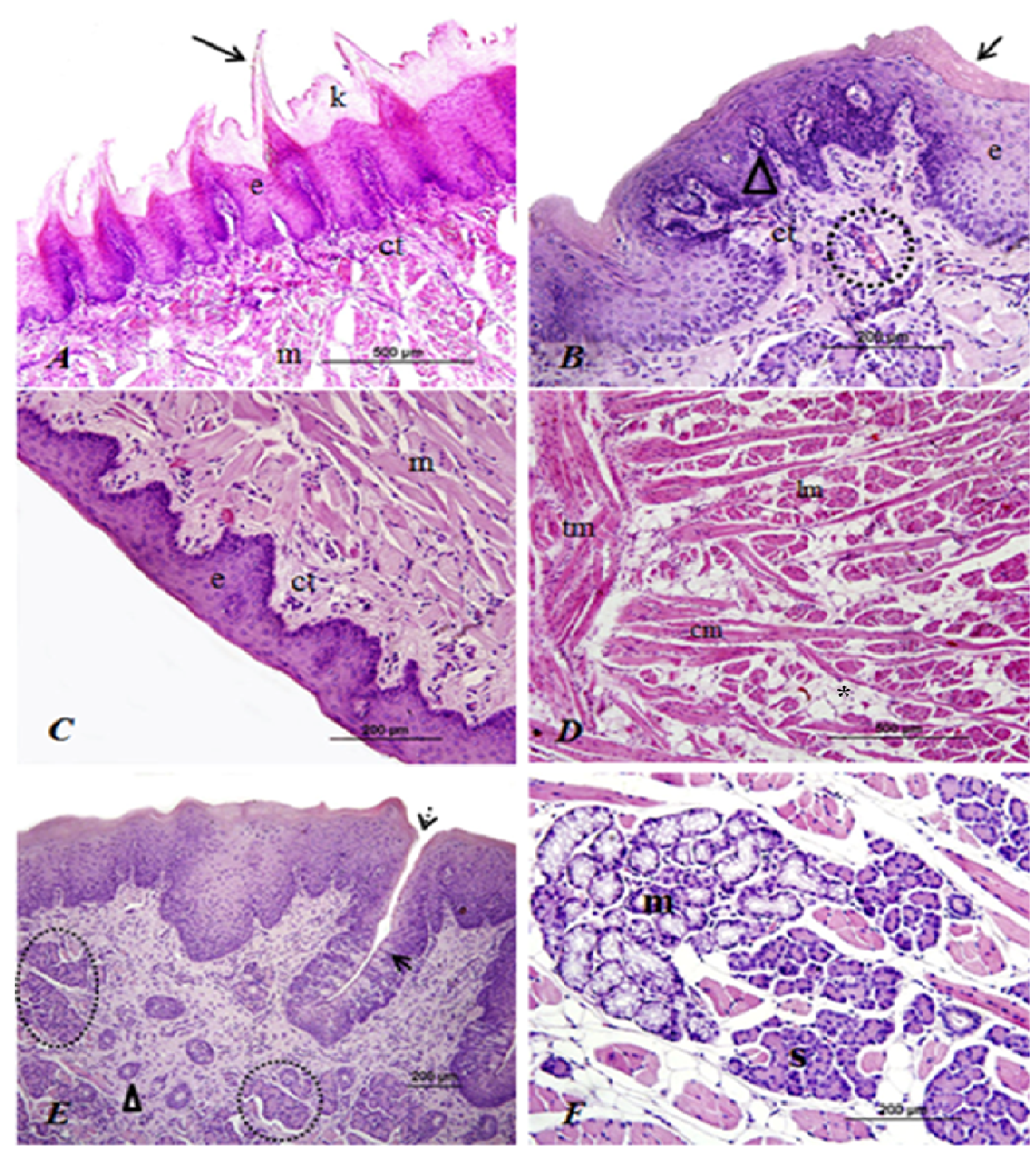

Figure 3. Photomicrograph of the tongue of $K$. rupestris stained with HE. A: filiform papillae (arrow) lined by keratinized (k) stratified epithelium (e), connective tissue (ct), and muscular layers (m). Bar: $500 \mu \mathrm{m}$. B: fungiform papillae lined by keratinized (arrow) stratified epithelium (e), and taste bud (arrowhead), a blood vessel (dotted circle) in the non-modeled dense connective tissue (ct). Bar: $200 \mu \mathrm{m}$. C: stratified epithelium (e), non-modeled dense connective tissue (ct) and muscular layers (m) at the ventral region of the tongue. Bar: $200 \mu \mathrm{m}$. D: circular $(\mathrm{cm})$, longitudinal $(\mathrm{lm})$, and transversal (tm) muscular layers and unilocular adipose tissue $(*)$. Bar: $500 \mu \mathrm{m}$. E: vallate papillae (dotted arrow) with taste buds (arrow) and serous acini (circle) with ducts (arrowhead) in the connective tissue. Bar: $200 \mu \mathrm{m}$. F: serous (s) and mucous (m) acini. Bar: $200 \mu \mathrm{m}$. 

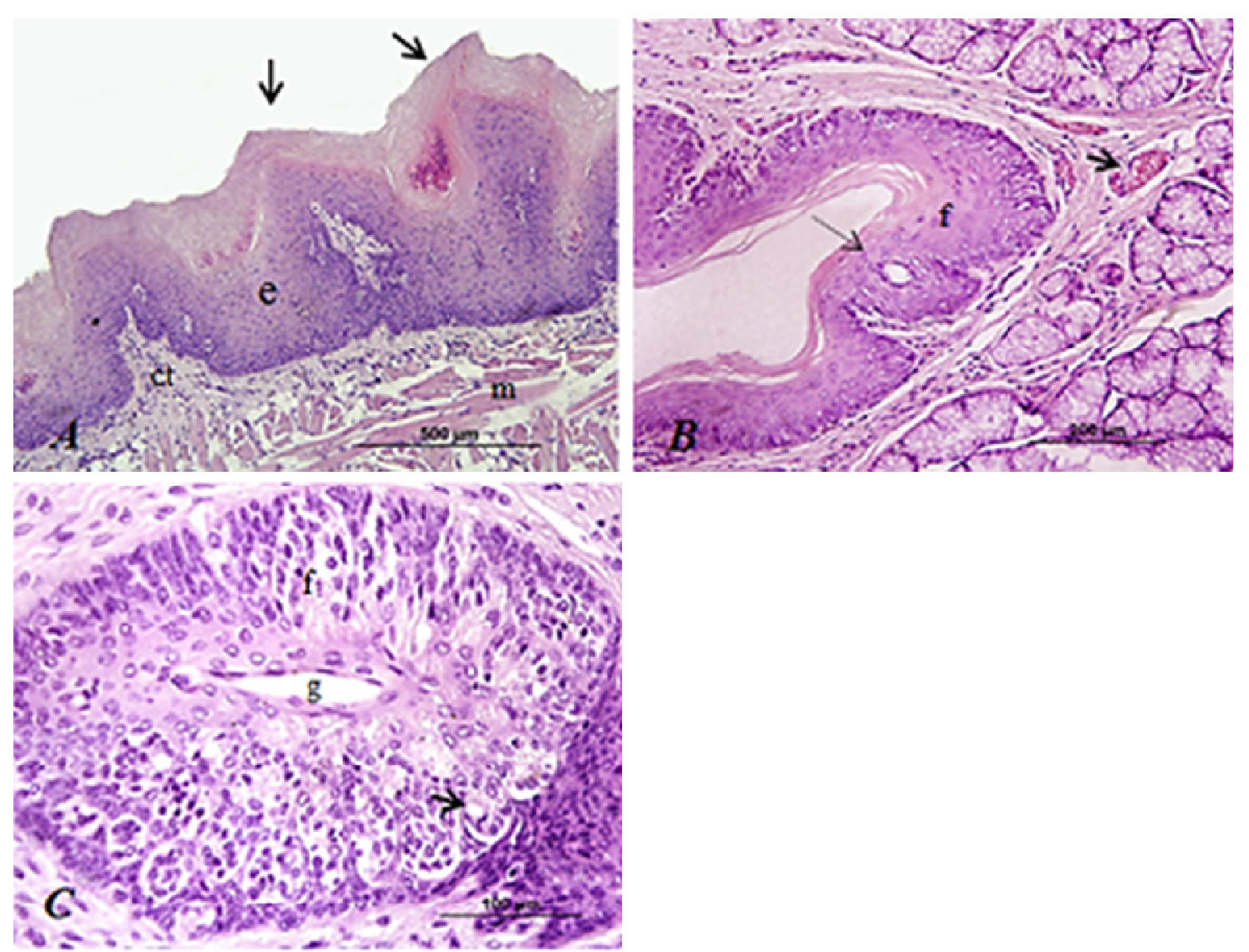

Figure 4. Photomicrograph of the tongue of $K$. rupestris stained with HE. A: conical papillae (arrows); keratinized stratified epithelium (e); connective tissue (ct) and muscular layer (m). Bar: $500 \mu \mathrm{m}$. B: foliated papillae (f); taste bud with its taste pore (dotted arrow) and blood vessels (arrow). Bar: $200 \mu \mathrm{m}$. C: transversal cut of foliated papillae (f) with their taste buds with taste pore (arrow) and papillary groove (g). Bar: $100 \mu \mathrm{m}$.

\section{DISCUSSION}

The tongue of $K$. rupestris is an organ with a rich skeletal striated muscular layer, characterized by an intermolar eminence in the root region, as described in other rodents, as Cavia porcellus (IWASAKI; MIYATA, 1985; KOBAYASHI, 1990), Clethrionomys glareolus (JACKOWIAK; GODYNICKI, 2005), Castor canadensis (SHINDO; YOSHIMURA; KOBAYASHI, 2006), Hystrix cristata (KARAN et al., 2011), Sciurus vulgaris (ÜNSALDI, 2010), Arvicanthis niloticus (NASR; GAMAL; ELSHEIKH, 2012) and in lagomorph Oryctolagus cuniculus (NONAKA; ZHENG; KOBAYASHI, 2008). Shindo, Yoshimura and Kobayashi (2006) and Nonaka, Zheng and Kobayashi (2008) also reported that the intermolar eminence may be found in artiodactyls, rodents, rabbits and marsupials, and all these species have herbivorous food habit. Silva, Watanabe and Kronka (2002) named the intermolar eminence as torus in Oryctolagus cuniculus.
The median groove found on the apex of tongue of the rodents Clethrionomys glareolus (JACKOWIAK; GODYNICKI, 2005), Sciurus vulgaris (ÜNSALDI, 2010), Spalax ehrenbergi (KILINC et al., 2010), Arvicanthis niloticus (NASR; GAMAL; ELSHEIKH, 2012), Hystrix cristata (KARAN; YILMAZ; AYDIN, 2011) and rats (IWASAKI; YOSHIZAWA; KAWAHARA, 1997) was not found in $K$. rupestris, on the other hand, a sagittal eminence was present in this region. References to these structures were not found in other rodents, but these eminences could be related to the anatomy and physiology of mastication and swallowing (CHENG et al., 2002). In this sense, we believe that these eminences may be important to capture food by assisting incisor teeth. In addition, these eminences may reflect adjustments in the bony structures of the palate. So, further studies of the oral cavity in $K$. rupestris are needed, in order to elucidate the importance of these eminences to the capture, mastication and swallowing process of food. 
The lingual papillae of $K$. rupestris were irregularly distributed on the dorsal surface of the tongue, as described in Cavia porcellus (KOBAYASHI, 1990), in wild carnivores as Nasua nasua (SOUZA et al., 2012.), in marsupials as Didelphis marsupialis (MANÇANARES et al., 2012.); in domestic mammals as Felis catus and Oryctolagus cuniculus (CHAMORRO et al., 1987); and, primates as Saimiri sciureus (BRANCO et al., 2011.) and Callithrix penicillata (BRANCO et al., 2012), besides other non-mammalian vertebrates such as amphibians, reptiles and birds (IWASAKI, 2002).
SANTOS, A. C.

Five types of lingual papillae were found in $K$. rupestris: filiform, conical, fungiform, foliated and vallate. However, some studies in other rodent species do not cite foliated or conical papillae (UTIYAMA et al., 1995; SHINDO; YOSHIMURA; KOBAYASHI, 2006; ÜNSALDI, 2010; EMURA et al., 2011). In Cavia porcellus, coronal papillae are described on the intermolar eminence (IWASAKI; MIYATA, 1985). To aid understanding the different distributions of the lingual papillae in different species, Table 1 shows their distribution in several rodents and non-rodents species.

Table 1. Lingual papillae available in rodents and other mammals.

\begin{tabular}{|c|c|c|c|c|c|}
\hline \multirow{2}{*}{$\frac{\text { Specie/author }}{\text { Rodentia }}$} & \multicolumn{5}{|c|}{ Types of papillae } \\
\hline & Filiform & Fungiform & Foliated & $\begin{array}{l}\text { vallate } \\
(\mathrm{n})\end{array}$ & conical \\
\hline Current research & + & + & + & $+(2)$ & + \\
\hline Cavia porcellus (KOBAYASHI, 1990) & + & + & + & $?$ & + \\
\hline $\begin{array}{l}\text { Clethrionomys glareolus (JACKOWIAK and } \\
\text { GODYNICKI, 2005) }\end{array}$ & + & + & + & $+(1)$ & + \\
\hline Dolichotis patagonum (EMURA et al., 2011) & + & + & + & $+(2)$ & - \\
\hline Castor Canadensis (SHINDO et al., 2006) & + & + & + & $+(3)$ & - \\
\hline Sciurus vulgaris (ÜNSALDI, 2010) & + & + & + & $+(3)$ & - \\
\hline Calomys callosus (UTIYAMA et al., 1995) & + & + & + & $+(1)$ & - \\
\hline Spalax ehrenbergi (KILINC et al., 2010) & + & + & - & $+(2)$ & - \\
\hline Arvicanthis niloticus (NASR et al., 2012) & + & + & - & $+(2)$ & - \\
\hline No Rodentia & & & & & \\
\hline $\begin{array}{l}\text { Didelphis marsupialis (MANÇANARES et al., } \\
\text { 2012) }\end{array}$ & + & + & - & $+(3)$ & - \\
\hline $\begin{array}{l}\text { Oryctolagus cuniculus (SILVA et al., 2002; } \\
\text { NONAKA et al., 2008) }\end{array}$ & + & + & + & $+(2)$ & - \\
\hline Nasua nasua (SOUZA et al., 2012) & + & + & - & $+(9)$ & + \\
\hline Felis catus (CHAMORRO et al., 1987) & + & + & + & $+(6)$ & + \\
\hline Callithrix penicillata (BRANCO et al., 2012) & + & + & - & $+(3)$ & - \\
\hline Saimiri sciureus (BRANCO et al., 2011) & + & + & + & $+(3)$ & - \\
\hline
\end{tabular}

In present study, the vallate papillae had rectilinear grooves, but in other rodents as Clethrionomys glareolus (JACKOWIAK; GODYNICKI, 2005), these papillae have V-shaped format. In Spalax ehrenbergi (KILINC et al., 2010) and Calomys callosus (UTIYAMA et al., 1995), they have an oval shape, surrounded by a deep groove. The vallate papillae of $K$. rupestris still had many taste buds as described in lagomorphs Oryctolagus cuniculus (NONAKA; ZHENG; KOBAYASHI, 2008), in wild carnivores Nasua Nasua (SOUZA et al., 2012), in marsupials Didelphis marsupialis (MANÇANARES et al., 2012) and human (WITT; REUTTER, 1997). Nonaka, Zheng and Kobayashi (2008) reported that the vallate papillae are present in varying numbers, from one in mice and rats up to 10-20 in cattle, sheep, goats and deer. On the other hand, mucous and serous acini found in the same tongue of $K$. rupestris were not described in these above described species.

By histology, taste buds present in fungiform papillae of the tongue of $K$. rupestris were described in other rodents, such as Castor canadensis (SHINDO; YOSHIMURA; KOBAYASHI, 2006) and Sciurus vulgaris (ÜNSALDI, 2010).

The many foliated papillae with taste buds found in our study are also reported by Kobayashi (1990) in Cavia porcellus. Shindo, Yoshimura and Kobayashi (2006) and Emura et al. (2011) reported that the development of foliated papillae in rodents is related to wide variety of food.

Keratinization found on the dorsal surface of the tongue of $K$. rupestris is also described in other rodents that inhabit environments with low 
humidity, as Clethrionomys glareolus (JACKOWIAK; GODYNICKI, 2005), Hystrix cristata (KARAN; YILMAZ; AYDIN, 2011) and Dolichotis patagonum (EMURA et al., 2011). Future studies may contrast the keratinization of the tongue from animals that inhabit dry and wet climate, in order to extract better conclusions on this point.

We conclude that the dorsal surface of the tongues of $K$. rupestris had filiform and conical papillae with mechanical function, and, fungiform, vallate and foliated papillae with taste buds responsible for gustatory function. Moreover, the tongue of these animals shows some peculiarities as the intermolar eminence and another eminence in sagittal plane at the apex, which needs further studies.

\section{ACKNOWLEDGEMENTS}

The authors would like to thank the Fundação de Amparo à Pesquisa do Estado de São Paulo (FAPESP) for its financial support in current research.

RESUMO: Os Kerodon rupestris são roedores silvestres criados em cativeiro para sua conservação e desenvolvimento de pesquisas. O objetivo deste estudo foi descrever a língua destes animais por meio de microscopia de luz, microscopia eletrônica de varredura e estudos macroscópicos. As línguas de K. rupestris tinham 3,15 $\pm 0,28 \mathrm{~cm}$ de comprimento; $1,00 \pm 0,20 \mathrm{~cm}$ de largura na raiz, $0,38 \pm 0,10 \mathrm{~cm}$ de largura no corpo e 1,10 $\pm 0,09$ de largura no ápice. As medidas de espessura foram $0,50 \pm 0,09 \mathrm{~cm}$ no ápice, $0,30 \pm 0,10 \mathrm{~cm}$ no corpo e 0,70 $\pm 0,10 \mathrm{~cm}$ na raíz. $\mathrm{O}$ ápice livre possuía 0,50 \pm 0,10 cm de comprimento. A superfície dorsal da língua continha papilas fungiformes e filiformes no ápice e corpo; papilas cônicas e um par de papilas valadas na raiz; e, papilas foliadas posicionadas dorsolateralmente na região da raiz. A lâmina própria da superfície dorsal da língua estava composta por epitélio estratificado pavimentoso queratinizado, no qual as papilas linguais foram encontradas; e, uma rica rede de músculo estriado esquelético e tecido conjuntivo denso não modelado, no qual veias, nervos e ácinos serosos e mucosos e seus respectivos ductos foram encontrados. Em conclusão, a superfície da língua de $K$. rupestris apresentou papilas filiformes e cônicas com função mecânica e papilas fungiformes, valadas e foliadas com botões gustativos responsáveis pela função gustativa. Além disso, a língua desses animais apresentou ainda particularidades, como uma eminência no plano sagital do ápice que necessita de futuros estudos.

PALAVRAS CHAVE: Aparelho digestório. Cavidade Oral. Papilas linguais. Roedores silvestres.

\section{REFERENCES}

ADRIAN, O.; SACHSER, N. Diversity of social and mating systems in cavies: a review. J. Mammal., Lawrence, v. 92, n. 1, p. 39-53, 2011.

BORSARI, F. N.; MARTINS, L. L; REIS, A. C. G; CRUZ, C; OLIVEIRA, M. F.; MACHADO, M. R. F. Análise macroscópica e microscópica do estômago do mocó (Kerodon rupestris). Pubvet, Londrina, v. 4, n, 24, p. 868-868, 2010.

BRANCO, E.; GUIMARÃES, J. P.; MIGLINO, M. A.; LACRETA-Jr, A. C. C; ISHIZAKI, M. N.; GOMES, B. D.; MUNIZ, J. A. P. C.; IMBELONI, A.; FIORETTO, E. T.; LIMA, A. R. Ultrastructural aspects of lingual papillae in squirrel monkey (Saimiri sciureus). Micros. Res. Tech., Malden, v. 74, n. 6, p. 484-487, 2011.

BRANCO, E.; PEREIRA, W. L.; DE LIMA, A. R.; FRANCIOLLI, A. R.; RICI, R. E.; MIGLINO, M. A.; MUNIZ, J. A.; IMBELONI, A. Ultrastructural aspects of Callithrix penicillata lingual papillae. Micros. Res. Tech., Malden, v. 75, n. 3, p. 282-284, 2012.

CHAMORRO, C. A.; SANDOVAL, J.; FERNANDEZ, J. G.; FERNANDEZ, M.; PAZ, P. Estudio comparado de las papilas linguales del Gato (Felis catus) y del Conejo (Oryctolagus cuniculus) mediante el microscópio electronico de barrido. Anat. Histol. Embryol., Malden, v. 16, n. 1, p. 37-47, 1987.

CHENG, C-F.; PENG, C-L.; CHIOU, H-Y.; TSAI, C-Y. Dentofacial morphology and tongue function during swallowing. Am. J. Orthodont. Dent. Orthoped., Seattle, v. 122, n. 5, p. 491-499, 2002. 
EMURA, S.; OKUMURA, T.; CHEN, H. Morphology of the lingual papillae in the Patagonian cavy. Okajimas Folia Anat. Japonica, Tokyo, v. 88, n. 3, p. 121-125, 2011.

IWASAKI, S-I. Evolution of the structure and function of the vertebrate tongue. J. Anat. Malden, v. 201, n. 1, p. 1-13, 2002.

IWASAKI, S-I.; MIYATA, K. Studies on the lingual dorsal epithelium of the Guinea Pig by Scanning Electron Microscopy. Okajimas Folia Anat. Japonica, Tokyo, v. 61, n. 6, p. 423-436, 1985.

IWASAKI, S-I.; YOSHIZAWA, H.; KAWAHARA, I. Study by Scanning Electron Microscopy of the morphogenesis of three types of lingual papilla in the Rat. Anat. Records, Malden, v. 247, n. 4, p. 528-541, 1987.

JACKOWIAK, H.; GODYNICKI, S. The distribution and structure of the lingual papillae on the tongue of the bank vole Clethrionomys glareolus. Folia Morphol., Warsz, v. 64, n. 4, p. 326-333, 2005.

KARAN, M.; YILMAZ, S.; AYDIN, A. Morphology of the filiform lingual papillae in Porcupine (Hystrix cristata). Anat. Histol. Embryol., Malden, v. 40, n. 2, p. 100-103, 2011.

KILINC, M.; ERDOGAN, S.; KETANI, S.; KETANI, M. A. Morphological study by Scanning Electron Microscopy of the lingual papillae in the middle east blind Mole Rat (Spalax ehrenbergi, Nehring, 1898). Anat. Histol. Embryol., Malden, v. 39, n. 6, p. 509-515, 2010.

KOBAYASHI, K. Three-dimensional architecture of the connective tissue core of the lingual papillae in the guinea pig. Anat. Embryol., Berlin, v. 182, n. 3, p. 205-213, 1990. http://dx.doi.org/10.1007/BF00185514

MANÇANARES, C. A. F.; SANTOS, A.C.; PIEMONTE, M. V.; VASCONCELOS, B. G.; CARVALHO, A. F.; MIGLINO, M. A.; AMBRÓSIO, C. E.; ASSIS-NETO, A. C. Macroscopic and microscopic analysis of the tongue of the Common Opossum (Didelphis marsupialis). Micros. Res. Tech., Malden, v. 75, n. 3, p. 13291333, 2012.

NASR, E. S.; GAMAL, A. M.; ELSHEIKH, E. H. Light and scanning electron microscopic study of the dorsal lingual papillae of the rat Arvicanthis niloticus (Muridae, Rodentia). J. Am. Sci. New York, v. 8, n. 4, p. 619$627,2012$.

NONAKA, K.; ZHENG, J. H.; KOBAYASHI, K. Comparative morphological study on the lingual papillae and their connective tissue cores in rabbits. Okajimas Folia Anat. Japonica, Tokyo, v. 85, n. 1, p. 57-66, 2008.

OLIVEIRA, G. B.; ALBUQUERQUE, J. F. G.; RODRIGUES, M. N.; PAIVA, A. L. C.; MOURA, C. E. B.; MIGLINO, M. A.; OLIVEIRA, M. F. Origem e distribuição do nervo femoral do mocó, Kerodon rupestris (Cavidae). Pesq. Vet. Brasileira, Rio de Janeiro, v. 31, sup. 1, p. 84-88, 2011.

RODRIGUES, M. N.; OLIVEIRA, G. B.; PAULA, V. V.; SILVA, A. R.; ASSIS NETO, A. C.; MIGLINO, M. A.; OLIVEIRA, M. F. Microscopy of the umbilical cord of Rock Cavies- Kerodon rupestris Wied, 1820 (Rodenta, Caviidae). Micros. Res. Tech., Malden, v. 76, n. 2, p. 419-422, 2013.

SANTOS, A. C.; BERTASSOLI, B. M.; VIANA, D. C.; VASCONCELOS, B. G.; OLIVEIRA, M. F.; MIGLINO, M. A.; ASSIS-NETO, A. C. The morphology of female genitalia in Galea spixii (Caviidae, Caviinae). Biosc. J., Uberlândia, v. 30, n. 6, p. 1793-1802, 2014.

SHINDO, J.; YOSHIMURA, K.; KOBAYASHI, K. Comparative morphological study on the stereo-structure of the lingual papillae and their connective tissue cores of the American Beaver (Castor canadensis). Okajimas Folia Anat. Japonica, Tokyo, v. 82, n. 4, p. 127-137, 2006. 
SILVA M. C. P.; WATANABE, I-S.; KRONKA, M. C. Three-dimensional architecture of the connective tissue core and surface structures of the lingual papillae in the rabbit. Histol. Histopathol., Murcia, v. 17, n. 2, p. 455461, 2002.

SOUZA, A. F.; OLIVEIRA, V. C.; SANTOS, A. C.; ROSA, R. A.; CARVALHO, A. F.; AMBRÓSIO, C. E.; MANÇANARES, C. A. F. Morfologia macro e microscópica das papilas linguais do quati. Pesq. Vet.

Brasileira, Rio de Janeiro, v. 32, n. 3, p. 271-277, 2012.

THOMAZ, J. M.; CARVALHO, A. F.; MIGLINO, M. A.; MANÇANARES, C. A. F.; AMBRÓSIO, C. E.; OLIVEIRA, M. F. Caracterização morfológica dos dentes de mocó Kerodon rupestris: Mammalia: Rodentia. Braz. J. Vet. Res. Ani. Sci., São Paulo, v. 43, n. 5, 702-707, 2006.

UTIYAMA, C.; WATANABE, I-S.; KONIG-JR, B.; KOGA, L. Y.; SEMPRINI, M.; TEDESCO, R. C. Scanning electron microscopic study of the dorsal surface of the tongue of Calomys callosus mouse. Ann. Anat., Philadelphia, v. 177, n. 6, p. 569-572, 1995.

ÜNSALDI, E. Macroscopic and Light Microscopic Structure of Fungiform Papillae on the Tongue of Squirrels (Sciurus vulgaris). Kafkas Üni. Vet. Fakült. Derg., Kars, v. 16, n. p. 115-118, 2010.

WITT, M.; REUTTER, K. Scanning Electron Microscopical Studies of Developing Gustatory Papillae in Humans. Chem. Senses, Oxford, v. 22, n. 6, p. 601-612, 1997. http://dx.doi.org/10.1093/chemse/22.6.601

ZOGNO, M. A.; MIGLINO, M. A.; OLIVEIRA, M. F. Análise bioquímica dos líquidos fetais e citologia do fluido amniótico da fêmea de Mocó (Kerodon rupestris). Braz J. Vet. Res. Ani. Sci., São Paulo, v. 41, n. 4, p, 228-235, 2004. 